\title{
4 \\ Overseas-born youth in Tongan
high schools: Learning the hard life
}

Helen Lee

Abstract

As the Tongan diaspora continues to grow it is increasingly common for the overseas-born children of migrants to attend high school in Tonga for one or more school terms. Sometimes the children themselves initiate the move and are keen to experience Tonga for themselves and 'understand the culture'. However, other young people have no say in this decision and many perceive their move to Tonga as a form of punishment. My paper explores the discourse around this form of mobility, focusing on ideas around risk, redemption and rite of passage. Tongans have divergent opinions about the value of this 'return' to the parents' homeland and there can be markedly different outcomes for the young people involved. Some Tongans point to the difficulties experienced by overseas-born youth, who are separated from their immediate family, friends and familiar environment and find themselves in a cultural context that can be extremely challenging. However, others see youth sent to Tonga as 'the lucky ones' who benefit from their exposure to Tongan culture and language. The young people who overcome the challenges of 'the hard life' in Tonga often value the experience as a way to become truly Tongan. 


\section{Introduction}

Return migration has often been depicted as a fraught and challenging form of mobility. Whether it is adult migrants returning after a long sojourn away from home, or their adult children's 'roots migration', or younger children going to their parents' homeland, the literature is replete with descriptions of feelings of alienation, marginalisation and identity confusion. This paper focuses on the overseas-born children of Tongan migrants who 'return' to Tonga in their youth to attend high school. Although in many ways they, too, can find this a difficult and even distressing experience, it is also important to recognise the more positive aspects of their time in their parents' homeland. The discourse surrounding this movement of youth from the diaspora to the homeland has a strong theme of risk and danger yet it can also be about redemption: the value of the time spent in Tonga to overcome problems experienced overseas and undergo a process of self-transformation. This discourse can even encompass that of a rite of passage, as youth from the diaspora travel to Tonga to experience 'the hard life' and 'learn the culture' in order to become 'truly' Tongan.

Overseas-born youth spend time in Tongan high schools for a range of reasons. The most common reason is that they are sent, often against their will, because of their family's concerns about their behaviour or the risk of negative influences overseas. Others choose to go and learn more about their Tongan heritage or to experience the life in Tonga they have heard about from older family members. Other reasons include being sent to the care of relatives after the death of a parent, or going to live with grandparents who want to spend time with them and cannot travel overseas themselves. In some cases, one or both parents go to Tonga with them for some or all of their stay; or parents may be returning to Tonga temporarily or attempting to resettle permanently after years overseas (Maron and Connell 2008); or one or both parents may even have been deported for overstaying their visas or because of a conviction for criminal activities (Lee 2009). There are also young people who, after being raised overseas by relatives, go to Tonga during their high school years to live with their biological parent/s for a period of time.

The diverse circumstances of young people's temporary migration to Tonga means that some are living with close family members while others are left in the care of relatives such as grandparents or aunts and uncles, 
who they may not have met before going to Tonga. Their family situation, and whether they attend high school as day students or boarders, as well as the other characteristics of the school they attend, have a significant influence on their experiences in Tonga. Their experiences are also shaped by their prior knowledge of Tonga and its culture. Although the language of 'return' is often used to describe this movement from the diaspora to Tonga, in reality many of the youth who arrive to attend school are visiting the country for the first time. They may not speak the language or have any depth of knowledge of the intricacies of anga fakatonga, the Tongan way. The many factors influencing each young person's time in Tonga makes it difficult to generalise but examining the discourse used by and about 'returned' youth reveals some common themes that offer starkly contrasting views of the value of this experience.

\section{Return migration through the generations}

The literature on return migration and transnationalism has paid scant attention to young people such as the Tongan adolescents that are the focus of this paper and has been more concerned with adult migrants and adult members of the second generation. Adults returning to the country in which they were born and raised can have problems readjusting and they may be regarded as 'outsiders' and no longer feel 'at home' (Gmelch 1980; Arowolo 2000; but cf. Howard and Rensel, this volume). This was the case for Tongan return migrants in a 2001 study (Maron and Connell 2008), who faced difficulties including being regarded as pālangi (white) and therefore not fully accepted.

In recent years the emerging literature on the 'return' of the adult children of migrants reveals that they find adjustment even more difficult than their parents. Susanne Wessendorf reports that Italians born and raised in Switzerland who move to Italy in what she calls 'roots migration' often find it difficult and feel 'trapped in a place which they once hoped would be their home, but in which they feel like strangers' (2007: 1097). Similar experiences are reported for the adult children of migrants from Greece (Christou and King 2006; Panagakos 2004), the Caribbean (Conway and Potter 2007: 20; Potter and Phillips 2006a, 2006b) and the Pacific (Connell 1990; and see Agarwal, this volume). Two edited volumes on this topic of 'return' migration of adult second and later generations (Conway and Potter 2009; Tsuda 2009) provide a range of other case studies that 
also describe the difficulties this movement can involve. Given that these studies all involve adults moving voluntarily, it seems highly likely that for adolescents, particularly those moving against their will, these problems will be even more acute.

As Madeleine Hatfield argues, the field of migration studies has not paid enough attention to either return migration or to children, and as a result children who return with their families to their 'home' country are 'doubly invisible migrants' (2010: 243). Even less attention has been paid to children who move alone to their parents' home country. However, in many migrant populations, including Tongans, young children are sent to the homeland to be cared for in order to enable their parents to work and avoid formal childcare, because parents are worried about their children's undocumented status, or due to concerns about social problems in the host country or their own children's behaviour. Yvonne Bohr and Connie Tse discuss 'satellite babies' who are sent by Chinese migrant parents in Canada to live with kin in China, so the parents can work and the children can be exposed to the language and culture of their homeland (2009). Their findings support other research that shows 'immigrant children who have been separated from their parents are more prone to depression as well as self-esteem and behavioral problems' (Bohr and Tse 2009: 269). ${ }^{1}$

Some research has acknowledged that overseas-born children spending time in their parents' homeland does not always have such damaging outcomes. In his study of migration from Mali to the Republic of Congo, Bruce Whitehouse (2009) shows that many parents send young children to Mali to be raised by kin, or send their children for school holidays. He suggests that because child fostering is so common in West Africa the separation of children from parents does not have some of the negative impacts reported in other cultural contexts. Similarly, Ernestina Tetteh (2008) claims fosterage is common and valued in Ghana, including the practice of 'posted children': babies and young children who are sent to Ghana by migrant parents so the parents can work and avoid the cost

1 Some of the issues raised in the work on sending children 'home' recur in research into other ways children are separated from their immediate family through migration. This includes being left behind with relatives when parents migrate, or children moving alone, for example to find work or to attend school overseas. Most importantly, these children are reported to experience the emotional stress of separation, deterioration of relationships with parents, difficulties at school, and behavioural problems (e.g. Dreby 2007; Matthei and Smith 1998; Moran-Taylor 2008; Parrenas 2001; Zhou 1998). As Dreby found in Mexico (2007) these experiences can be particularly acute for adolescents. 
of formal childcare. ${ }^{2}$ Tetteh found that young children sent to live with relatives in Ghana while their parents worked accepted this 'as a lifetime opportunity for them to make it in future' (2008: 5).

Positive perceptions of fostering may make it easier for such children to adjust to separation from migrant parents. Children's acceptance of their situation can also be influenced by the reasons for the separation. When sending children to the homeland is motivated by their parents' desire to achieve social and economic mobility for the family, children may perceive the short-term pain of separation as being worth the long-term gains. As Suarez-Orozco, Todorova and Louie have argued:

of critical importance to the adjustment process is how the child makes meaning of the situation of separation from parents and other loved ones. If the child is well prepared for the separation, and if the separation is framed as temporary and necessary, undertaken for the good of the family, the separation will be much more manageable than if the child feels abandoned (2002: 640).

When children are sent to the parents' homeland because of concerns about their behaviour the focus is primarily on the outcome for them as individuals rather than the benefit to other family members. This may be even more difficult to cope with than a sense of abandonment, since the child is likely to perceive the separation as his or her own fault and the move as a form of punishment. Even those who choose to spend time in the homeland are pursuing an individual identity journey rather than seeking to benefit their family, so they may feel less able to ask for support during their adjustment to the unfamiliar environment.

Studies of migrants' children going to the parents' homeland consistently show that older children and adolescents find the experience more difficult than younger children, especially those sent against their will. Young children sent to Ghana by migrant parents may accept their situation in the context of a common pattern of fosterage but older children have more negative attitudes, especially those whose parents send them for bad behaviour (Tetteh 2008). Tetteh reports they often live with relatives they barely know and are 'angry, bitter and unhappy about the whole arrangements to come to spend time in Ghana' (Tetteh 2008: 106; see also

2 I have described the 'brown paper parcel babies' in the Tongan case; infants sent from the diaspora to be cared for in Tonga (Lee 2003: 58). No detailed study has been done of these children although Kerry James has described them as 'a bond of love and living confirmations of kinship' while also expressing concern about the strain on families in Tonga (1991). 
Coe 2008: 234). These children have grown up overseas so Ghana is unfamiliar and they experience difficulties adjusting to their new schools. They also worry about 'missing out on a lot of things taking place back home and the fact their friends will be way ahead of them in everything and that fitting back into the system will be difficult' (Tetteh 2008: 108).

These children may be moving within a transnational social space and a network of kin, yet from their own perspective their movement is from familiar to unfamiliar social spaces.

Little research has been conducted into overseas-born youth returning 'home' to attend high school in Tonga or other Pacific countries. In the 1980s Cluny Macpherson briefly observed for Samoans in New Zealand that it was common for parents to send or take children to Samoa for periods of time, and that 'many adolescents reported a sense of alienation that surprised and hurt them' (1985: 250). My own earlier research includes a small study in Tonga in 2006, in which a group of 15 boys boarding at a Wesleyan college expressed similar feelings of alienation but tried to make the best of their situation (Lee 2009). They focused on the benefits of getting to know their relatives and Tongan culture while also acknowledging the hardships they were enduring in their new environment.

\section{Diasporic youth in Tongan high schools}

To explore in more depth the experiences of overseas-born youth in Tongan high schools, research was conducted in Tonga in 2013. Two Tongan researchers, Rebecca Tauali $\mathrm{i}$ and Ebonie Fifita, worked in six high schools on Tongatapu for the project. This involved working with small groups of overseas-born students (hereafter 'the students') at each school, holding weekly, two-hour 'talanoa sessions' with them for four weeks. ${ }^{3}$ The talanoa methodology has been described by Timote Vaioleti as 'a personal encounter where people story their issues, their realities and aspirations' with no rigid framework for the discussion (2006: 21). This kind of 'storying' approach has been widely used in Pacific research

3 In addition to the talanoa sessions, a total of 144 detailed questionnaires were completed by students from one class in each of five schools. Interviews also were conducted for the project with Tongan adults in Australia, New Zealand and Tonga by the author, Rebecca Tauali' $i$ and Hainoame Fulivai. Hainoame also set up, with Meliame Fifita, two Facebook sites for the project. 
and is particularly effective for working with youth. The students were guided through unstructured discussions of their experiences in Tonga by Rebecca and Ebonie, who had general themes for each week but allowed the students to direct the conversation to issues that concerned them, as well as engaging in a lot of joking and chat that helped them feel at ease. ${ }^{4}$ In the final week they created colourful posters (see Figure 1) on which they were invited to make statements they wanted to get across to their families, teachers and schoolmates about their experiences. ${ }^{5}$
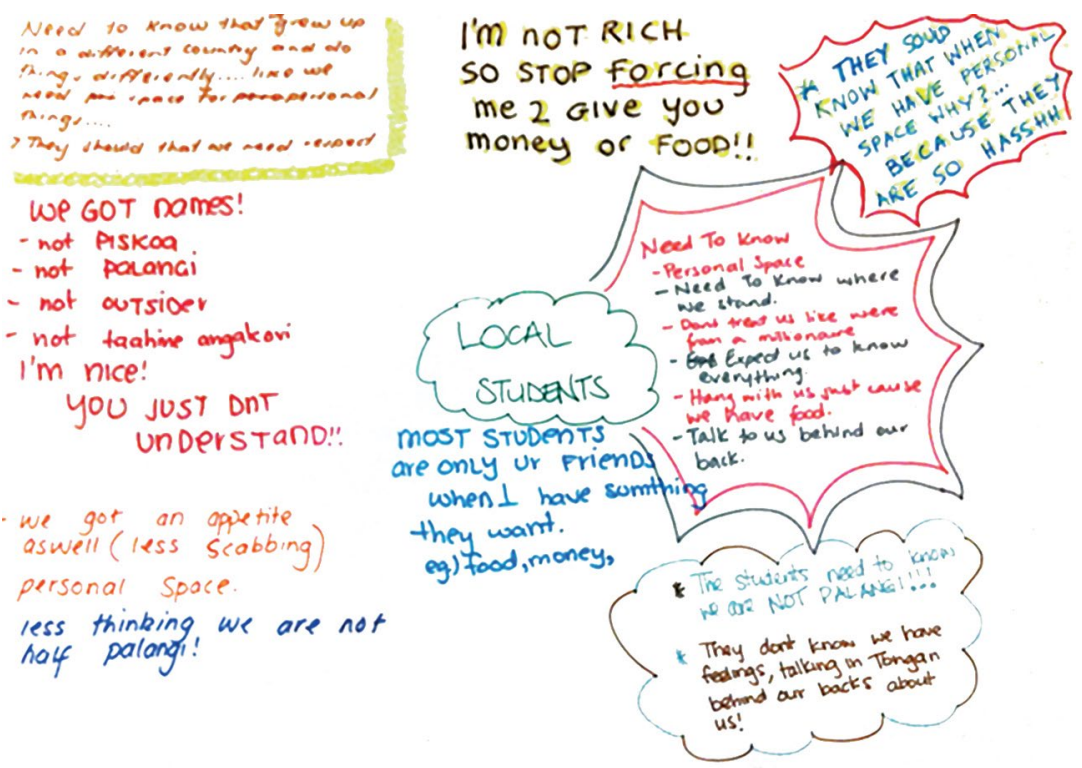

Figure 1: An example of the posters made by students Source: Photographed by author.

The 28 students ranged in age from 11 to 19 but most were 15 to 17 and were from Australia, New Zealand, the US, Samoa and Fiji. There were 18 females and 10 males involved in the talanoa sessions, with the gender imbalance due to girls being more willing to volunteer to participate in

4 The students were also given cameras and invited to take photographs to capture their daily lives and things they cared about. Each week they discussed their photos with the researchers. They kept the cameras after the project concluded and were given USB sticks with copies of all their photographs.

5 The posters and the discussion sessions were used in a report on the research findings, "'The lucky ones"? Overseas born Tongan youth in Tongan high schools'. It was presented in June 2015 to the Tongan Government, participating high schools and other key stakeholders involved with Tongan youth issues. 
the project. Anecdotal evidence suggests more males than females are sent to Tonga, however, no statistics are kept on overseas student numbers either by schools or the Ministry of Education and Training. Most of the students spoke little or no Tongan when they arrived in Tonga and only five said they already spoke Tongan very well. While one student had visited Tonga every year from an early age and another had been every two years, most had only visited once or twice and eight had never been to Tonga before arriving to attend school.

The schools they attend are very diverse. One is government-run and the others are Wesleyan, Mormon and Seventh-day Adventist. They are a mix of day and boarding schools, single sex and co-educational; located in the capital, Nuku'alofa, and out in the villages on the main island, Tongatapu. They differ significantly in other respects, such as the amount of English spoken in class and the quality of the buildings and student resources. For example, Liahona, the Mormon high school, is a day school, the classes are taught in English, and there are ample learning resources and support, including counsellors to deal with any problems. In contrast, the Wesleyan boarding school for boys, Tupou College, known as Toloa, holds most classes in Tongan, the boys are expected to do hard physical labour in the school gardens, the dormitories are dilapidated and crowded, and problems are often dealt with through harsh physical punishment rather than counselling. ${ }^{6}$

\section{'Potential trouble': The discourse of risk}

Tongan parents who send their older children to Tonga tend to frame their decision around a desire to give them the opportunity to spend time with kin and become familiar with the home language and culture, but they also are often intent on addressing what they perceive as bad behaviour. This can range from poor grades to rebellion to involvement with drugs and criminal activities. Sometimes it is a pre-emptive strike, to remove their child from negative influences before it is too late. In any case, their motives are interrelated-to ensure their children learn anga fakatonga as a way to 'straighten them out'.

6 When I revisited the school in 2015 a new principal was discouraging physical punishment of the boys, having new dormitories built and developing positive connections with other schools to address the problem of violent inter-school rivalry. 
However, the idea that sending 'youth at risk' to Tonga will improve their behaviour and remove them from dangerous influences (Schoone $2008,2010)$ contradicts the view held by some Tongans that this practice is itself putting them at risk. Both in Tonga and in the diaspora some believe sending troubled youth to Tonga is the only way to deal with their behavioural problems while others are equally adamant that it can psychologically damage children and create readjustment problems for them when they return overseas (Lee 2003: 86-89). In addition, the practice is seen as creating a risk for the country of Tonga and the families that are given the responsibility of caring for these young people.

\section{Risks for the 'returned' youth}

The main focus of concern for the wellbeing of overseas-born youth in Tonga is those sent because of perceived behavioural problems. Sending, or threatening to send, youth to the parents' homeland has been described for some other migrant groups as 'transnational disciplining' (Orellana et al. 2001). The sparse literature on this practice, which includes migrant parents from the Caribbean (Barrow 2010; Guarnizo 1997), Guatemala (Menjivar 2002), Belize (Matthei and Smith 1998), and Ghana (Tetteh 2008), shows behavioural and emotional problems are common as a result of being sent away from home and exacerbated when the young person feels abandoned by their parents (Suarez-Orozco et al. 2002).

Most of this research focuses on migrants in the US. Cecilia Menjivar (2002) found that Guatemalan immigrants in Los Angeles send their children 'home' when concerned about their involvement with gangs and crime. She reports that the children saw their move as 'punishment' and were unhappy, had difficulty communicating and did not understand cultural expectations of them. They were placed in a 'vastly different milieu living with people they could hardly recognise as family' (Menjivar 2002: 545). The impact on such young people's education is also of concern; for example, in Mexico some 'returned' students benefit from exposure to the language and culture of their parents' homeland while others remain 'between cultures' and their education suffers (Zúñiga and Hamann 2009). Research with Central American, Mexican and Yemeni migrants (Orellana et al. 2001) shows children sent to the parents' home country had difficulties with schooling after being used to all-English classes in the US. 
The idea of the homeland as a space of discipline and enforced 'culture' is interesting in the Tongan context because Tongan homes, while usually spaces of love and laughter, are also typically spaces of discipline, with expectations that Tongan culture will be enacted. Sending youth from the diaspora to Tonga because of their behaviour is effectively an admission there has been a failure in the home to properly discipline a child and he or she is therefore 'at risk'. It is seen as an attempt to ensure proper discipline and cultural learning occurs in a space-that is, Tonga itself and in the homes of kin in Tonga-perceived as relatively safe from the risk of the external influences that undermine Tongan culture in the diaspora.

There is a tendency in Tonga for older, more conservative church and community leaders, who have limited direct contact with diasporic youth, to claim mostly positive outcomes for youth sent to Tonga. A leading figure in the Free Wesleyan Church claimed that 'more than 80 per cent' of cases of youth who are sent to Tonga are 'good stories'. However, those who have on-the-ground experience with these young people are typically more negative in their assessments. In fact, a representative of a prominent civil society organisation working with youth in Tonga said it was 'rare' that sending youth to Tonga actually helped them. People who work with youth in Tonga described a whole range of behavioural and emotional problems young people coming from overseas can experience and were concerned that most are not being given much support, if any. For example, in 2013 only two high schools had professional counsellors, and overseas-born youth are not acknowledged in most of the work being done around youth issues, such as the Tonga National Youth Strategy (Ministry of Training, Employment, Youth and Sports 2007). Even those who were positive about diasporic youth going to Tonga admitted that some of them do not cope well with the experience and have to return overseas.

In addition to the emotional problems associated with an unfamiliar and often challenging environment and separation from their immediate family, youth sent because of behavioural concerns face the danger of over-zealous relatives and others such as teachers and prefects harming them in their attempts to discipline them. ${ }^{7}$ Even youth who have chosen to go to Tonga may experience violence in various contexts, in

7 In 2007 the Attorney General of Tonga at that time, Mrs 'Alisi Taumoepeau, told me of two cases of teenagers who had been sent to Tonga and had died at the hands of relatives who were attempting to 'straighten them out' using physical punishment. 
the form of punishment from those of higher status and aggression from peers. Boys often get caught up in the intense inter-school rivalries that frequently erupt into violence including large-scale brawls in the streets. One of the boys in the discussion groups described being trapped on a bus with boys from a rival school who hit him repeatedly with a piece of wood; he had to have plastic surgery to repair his face. Some Tongans regard such experiences of violence as an inevitable part of adjusting to Tongan life. An older, high ranking man in Tonga told me that overseas-born youth should learn to fit in or they could expect 'to end up in hospital'.

Adults who grew up overseas and spent time in Tonga as adolescents draw on the discourse of risk in reflecting on their own experiences. Sela, a woman now in her 30s, had a particularly difficult experience. She grew up in New Zealand and went to Tonga at the age of 11 for what she thought was a family holiday but was left in Tonga with her grandparents because her younger brother had chosen to stay. She enjoyed being in Tonga while it was a holiday, 'But as soon as I was told I would remain there, Tonga just became my worst nightmare-literally'. She hated being a boarding student at Queen Sālote College, where she struggled with the language, the hard physical work expected of the students, and the regular physical punishment she witnessed and experienced. She described her stay as like being 'lost in the wilderness' or 'stuck in a female prison in a foreign country'. Although she stayed for eight months she never liked being in Tonga and was constantly homesick.

Sela eventually became ill from refusing to eat, developed eczema that led to bad skin infections, and suffered anxiety. The final straw was when her teacher hit all the students in her class for failing a test and Sela went back to her grandparents' house in distress, with bruises and welts on her hands and up her arms. Her grandfather took her out of the school immediately and soon sent her back to New Zealand. Sela's case is an extreme example but it is not uncommon for the young people who go to Tonga to find the experience so difficult they are sent back overseas. One of the boys who participated in the school discussion sessions was so unhappy at his school he was deliberately getting into trouble, hoping he would be 'deported back to NZ'. 


\section{Risk for Tongan society}

Sending children 'home' from the diaspora can have negative consequences for the home country, as has been shown in a range of studies of the 'return' of migrants' children. For example, youth sent 'under punishment' to Belize in the 1990s had 'transnationalised' the Los Angeles gangs they belonged to and were negatively influencing young people raised in Belize, particularly those with absentee migrant parents (Matthei and Smith 1998: 284). It can also place strain on schools when students have poor language skills and are used to a different education system (Zúńiga and Hamann 2009: online). Luis Guarnizo reports that for Dominican migrants the decision to send children 'home' is 'often against the child's will' (1997: 301) and there are usually negative consequences, including the impact of family separation and the increased economic burden of sending money to support the children. There is also strain on ties with kin in the homeland: 'Fewer and fewer relatives have been willing to accept the considerable burden of caring for returned children and adolescents because of their difficult behavior' (Guarnizo 1997: 301).

The burden on families in Tonga and the difficulties posed for schools are certainly of concern in Tonga, however, the major risk these young people are perceived to bring is their 'bad influence'. Overseas-born youth living in Tonga are often regarded as much the same as the deportees who are increasingly being sent to Tonga by overseas governments, particularly from the US. Many of the deportees are young men who have been convicted of crimes and they are regarded with considerable hostility by most Tongans (Esser 2011; Lee 2009: 43; Pereira 2011). Just as deportees are blamed for rising rates of crime and violence in Tonga, youth from the diaspora, particularly those sent for bad behaviour, are accused of bringing social problems such as substance abuse and are blamed for the increasingly violent clashes between rival 'gangs' and between some of the high schools. One older male from a civil society organisation claimed the diasporic youth bring 'skills to do harm' and expressed the common view that they are a negative influence on the youth of Tonga.

A senior member of the Ministry of Education and Training confirmed the overseas-born youth and deportees tend to be seen as one category: 'potential trouble'. She said Tongans see the youth as 'bad' and admitted they tend to be 'blamed for anything bad that happens'. Another senior ministry representative confirmed that these youth are often blamed for instigating any trouble, particularly boys in relation to the inter-school 
fighting, which seems to be escalating and involving more use of weapons, which some claim have been brought from overseas by the youth. Rather than seeing them as victims of this violence they are depicted as instigators. More generally, overseas-born youth, both males and females, are often labelled as 'fie kovi' (literally: wanting to be bad) or anga kovi (bad by nature) as well as various versions of pälangi (white), which have negative connotations of bringing dangerous and unwanted influences.

The students were well aware of and strongly resented these negative labels. One of the posters they created has the exclamation: 'We're all the same, we are Tongans, so don't treat us like foreigners'. At another school, a girl wrote on her group's poster: 'We got names!- - not piskoa [Peace Corps]—not pālangi—not outsider—not ta'ahine angakovi [bad girl]. I'm nice! You just don't understand!'

\section{'The lost children': The discourse of redemption}

The term redemption, with its biblical connotations, seems appropriate to capture another common theme in discussions of diasporic youth going to Tonga, which is that of being saved from real or potential problems. As the corollary of 'risk' it encompasses ideas of rescue and rehabilitation. It also captures the motives of their families in removing them from the perceived risks that exist overseas and placing them in the Tongan context of culture and discipline.

This discourse focuses on the time in Tonga as a way to overcome behavioural problems and get on the right path—or be 'straightened out'. It is about a process of transformation where the individual returns overseas reformed and more properly 'Tongan'. The focus of this discourse tends not to be explicitly on the role of 'culture' in the transformation but on the positive impact of hard work and discipline, and the benefits of youth spending time with members of their extended kinship group. The focus is on changes in attitude and behaviour and often an association is made with the young person learning to appreciate the life they have overseas. By experiencing the 'hard life' in Tonga they realise they have it good overseas and should make the most of the opportunities there. 
The church leader mentioned above, who gave a positive view of the outcomes for overseas-born youth, drew on the classic Christian narrative of redemption in dramatic examples of what he called 'lost children' being saved by being sent to Tonga and returning overseas as much better people. He gave the example of a former drug addict who went home to 'instruct his parents on religious principles' and became a youth worker. The director of a civil society organisation, also an older male, repeated the claim that a high percentage of youth sent to Tonga have positive outcomes. Using the language of rehabilitation he observed: 'I think people see the whole island as a therapy so they assume when they send their kids they will come right'. He added: 'The few lucky ones are the ones whose parents cared enough to send them here. The unlucky ones don't come to Tonga'. He commented sarcastically that perhaps the parents of those 'unlucky' youth think they are safer in prison in Australia or the US.

The students who used this discourse of redemption were usually those who had been sent to Tonga because of concerns about their behaviour. A 16-year-old girl said she was in Tonga 'to suffer from what I was doing back in New Zealand'; a 14-year-old girl, also from New Zealand, admitted: 'the reason why I came is to change my attitude'; and a 15-yearold girl from Australia said she was there 'cause I need to change; change, yeah. Change my ways from before when I was back home'. When reflecting on the impact of their time in Tonga many students used the expression 'my attitude has changed' and when they elaborated, they typically included learning respect, being more obedient, being more helpful with chores and being more responsible in their behaviour. Others talked of a fundamental shift in their sense of self: they had become 'a new person' or 'a better person' or had 'found' themselves in Tonga.

When asked what might have happened if they had not been sent to Tonga most of these students claimed they had been rescued from their 'bad' behaviour becoming even worse. They talked about their siblings and friends 'back home' and how they could have ended up like them: pregnant at 16, drinking, smoking and taking drugs, getting into gangs and so on. They imagined they might have been expelled from school, or 'probably be kicked out of home' and 'out of control'. More dramatically, one boy said 'oh, either in prison or dead!' They had been saved from their former selves; as another boy put it: 'I used to think that I was better than anyone-right now I'm good, I'm all good and yeah, it's better here'. 
While some students were convinced their self-transformation was permanent, others were worried about how they might react to returning overseas. A few even said they wanted to stay in Tonga. As one boy admitted: 'I know when I go back I would go back to my old ways'. This concern about leaving Tonga often leads students to extend their time there, even when their families say they can return home. This was the case for Meg, a Tongan woman now in her 30s who grew up in Australia, who described her first year in Tonga as a youth in dramatically negative terms. She was sent to board at Queen Sālote College in her second-to-last year of high school, when her mother was concerned about her becoming rebellious, and her story of that time is full of incidents of hardship and harsh physical punishment from the teachers at the school she described as 'a jail' and 'a different world'. It took nearly a year for Meg to get used to her life in Tonga and to make friends, who were also girls sent from overseas. However, when she went home to Australia for Christmas at the end of that first year and her mother asked what she wanted to do, she replied: 'send me back'. She had been redeemed! She stayed in Tonga for another whole year, by choice, and explains: 'I felt like I needed to learn more. I wanted to understand the whole Tongan way. For me it was like getting down to my roots'.

Reflecting on her experience during her interview Meg cried and said she missed Tonga. She admitted living there taught her to appreciate what she had in Australia and helped her 'find herself' - as if she had been 'lost' before. Nevertheless, she hasn't been back to Tonga since then. She said: 'I haven't gone back 'cause I was traumatised by what I saw-the school, the classrooms, you know, the teachers, the way they are.' Risk and redemption, it seems, are closely interrelated and the need to undergo some form of 'suffering' in the process of claiming an authentic Tongan identity is often implicitly framed around the idea of a rite of passage.

\section{'Learn the Tonga life': Going to Tonga as a rite of passage}

Although the discourse around the 'return' of youth to Tonga as a rite of passage is less explicit than that around risk and redemption, there is a common trajectory described by both the youth themselves and the adults observing their experiences that closely fits the classic stages of separation, transition or liminality, and reincorporation (Turner 1967; 
Van Gennep 1960). The time spent in Tonga can be seen as a cultural rite of passage or initiation, including the process of 'hazing' by peers and the acquisition of important cultural knowledge through a series of stages leading to eventual acceptance by others as a 'real' Tongan.

\section{Separation: Arrival in Tonga}

Even for youth who have frequently visited Tonga before, arriving to stay for a lengthy period can be a daunting prospect and for those who are unfamiliar with life in Tonga it can be what many Tongan adults referred to as 'a huge shock' or 'a culture shock'. For some there is the added emotional impact of feeling abandoned by their parents, when after travelling to Tonga on what they think is a family holiday, they are told they will be staying and attending high school for a while. A 16-yearold boy born and raised in the US said when he arrived in Tonga he was 'mad, angry, unhappy, lonely' and others describe their homesickness, confusion and fears about life in Tonga.

The experiences of youth when they first arrive and begin school can be likened to the 'hazing' common to initiation rituals; it is a time when those in Tonga make it clear these overseas-born youth do not yet belong. A representative from a civil society organisation wryly observed, 'Tongan culture is not a sensitive culture', and it is certainly the case that the students from muli (overseas) are frequently teased and mocked by other students, and become the subject of gossip. Due to their poor Tongan language and cultural skills and the fact that they have grown up overseas, they may be derisively called pälangi (white), fie pälangi (wanting to be white), or pälangi loi (pretending to be white). Their clothes and belongings may be taken, particularly if they are in boarding school, and peers will assume that because they are from overseas they are relatively wealthy so will make constant demands on them.

In this 'liminal' stage they are confronted by an unfamiliar environment and their own lack of cultural knowledge. A common claim made by adults in Tonga when discussing diasporic youth was that migrant parents do not teach their children about Tongan culture and daily life; they are supposed to somehow just know. Then, when they get to Tonga, they may find no one there explains anything either; 'basically they feel lost', as a youth worker commented. A 17-year-old female student from Australia said of Tongan culture: 'before Tonga I didn't know what was going on'. In a discussion about this problem of not having anything 
explained, a 16-year-old girl from New Zealand said: 'I think they think we know, but we don't' and her friend (15, from Australia) added, laughing: 'we don't tell them that we don't know!'

\section{Liminality: 'Learning the culture'}

The cultural knowledge that youth lack was described by a senior member of the Ministry of Education and Training as the 'hidden curriculum'. Young people arriving from overseas quickly realise there is a great deal of knowledge they have to acquire in order to be truly Tongan. On their posters the students wrote pleas such as: 'give us time to adjust to the culture' and 'we're different from you so don't expect us to know everything'.

To be accepted and to cope with life in Tonga they have to acquire that cultural knowledge, especially to learn the language, figure out kinship rules and Tongan values and find their place in the social hierarchies with which they have to engage (family, school, church, etc.). ${ }^{8}$ They also learn to do hard work and to endure difficult conditions including cold water showers, lack of privacy, insects such as mosquitoes and fleas, and generally far less access to material goods, entertainment and technology than overseas. The students frequently summarised this as 'learn the Tongan life', which they often qualified as 'the hard life'. Both males and females described how they had learned to embody all this cultural knowledge, including their physical mastery of tasks like making an underground oven, building a fire to cook food outside or learning traditional Tongan dances. Their photographs for the project and those they put on their Facebook sites reflect this pride in becoming more Tongan and show them doing typical Tongan chores, or dressed in their traditional dance costumes, in their school uniforms or ready for church wearing formal Tongan clothing.

Despite their obvious pride in what they had learned there were many complaints during the school talanoa sessions about 'the hard life'. The students frequently bemoaned the amount of difficult physical work demanded of them both at home and at school—where in most cases

8 In a study of 'at-risk' New Zealand born Tongan youth sent to live in Tonga, Adrian Schoone $(2008,2010)$ has analysed their transformation as 're-scripting' their lives. Schoone describes the way these young people changed their 'personal narratives' through immersion in anga fakatonga (the Tongan way). 
students are expected to work in the school plantation, keep the grass cut around the school and undertake other maintenance tasks. Another common complaint was poor quality food and general lack of food, particularly from youth in the boarding schools. They described a diet of white rice, flour dumplings and bread, and starchy root vegetables. When asked what they missed most about living overseas an almost unanimous initial response was 'food!' followed by lists of the many varieties of food they could not get in Tonga. When asked what they hated most about being in Tonga, again the typical response was 'the food!'

Getting used to the hard life also entails learning how to manage one's emotions. For boys, this can be particularly challenging when confronted with different expectations around violence. A 17-year-old at Toloa, the boys' boarding school, who had grown up in the US and had only been to Tonga once before as a small child, admitted that when he arrived: 'I wasn't really used to Tongan life. I wasn't used to speaking the language, I wasn't used to like socialising with the kids, like especially [when] they play around. They play around a lot, very, very aggressively'. He observed that in the US if someone hit him hard, he would hit back: 'it's gonna be a fight'. In Tonga, he explained, 'it's just a joke. Like if someone hits, punches you in the ear and it hurts, you just laugh at it'. However, he ended his comments by adding that in the US 'everyone keeps to themselves. Out here everyone's open, everyone's friendly'. Continuing this conversation a 15-year-old boy said that when people mocked him, he had to 'let it go fast' and not react or he would get into trouble, 'so I just tend to control myself'. When asked: 'but overseas, if someone did it you'd knock them out?' the whole group of boys chimed in with an emphatic 'Yeah!'

As mentioned previously, both boys and girls have to learn to deal with the violence associated with physical punishment, although some had already experienced this within their families overseas. Boys tended to underplay this form of violence by joking about it just as they had learned to cope with 'friendly' violence from peers. Some attempted to sound blasé: 'Nah, getting used to it' or 'it's just like a few hidings and that's all'. The girls were less accepting of physical punishment, particularly at school, and one group in particular returned to this topic without prompting during every weekly discussion session and were clearly distressed by their experiences. Nevertheless, most of the students endured this punishment because they saw it as part of Tongan culture-apart from two girls who claimed that every time a teacher seemed likely to hit them they would yell: 'You can't hit me, I'm under New Zealand protection!' 
Throughout the school discussion sessions the cultural value the students referred to most often was respect. Part of their acquisition of cultural knowledge was learning to control their bodies in ways that met the cultural requirements for young people to show respect, as well as to be obedient and compliant. When in the presence of adults they had learned to keep their eyes downcast, to speak softly and never answer back, and to sit quietly for as long as required no matter how uncomfortable they may be. A 17-year-old girl from Australia summed it up:

I learned the Tongan culture by like always going to church and from home to church, home to school—no other place and stuff and I learned-you know how girls are supposed to respect boys too and how boys are supposed to respect girls? It is also about the clothes we wear at home-I have to wear respectable clothes and so I can't wear whatever I want because it might not be respectful to others. That's what I got.

\section{Reincorporation}

Not all young people who go to Tonga want to embrace Tongan culture and some struggle against it for their whole stay. Some, like Sela, have to return overseas because they simply cannot adjust to 'the hard life' and many emerge from their experience with a new appreciation of the comforts and opportunities they have in the diaspora. Although few return overseas completely unaffected by their time in Tonga, the experience is not always transformative. The most profound self-transformation is experienced by youth for whom the time in Tonga is effectively a rite of passage, as they acquire Tongan language and cultural knowledge and are eventually accepted as 'proper' or 'real' Tongans. Some wholeheartedly embrace their new status and become what I have previously called 'born again Tongans' (Morton 2002). Others use their experience in Tonga to learn to shift between different personae in order to fit changing contexts, until they are as comfortable with their 'Tonganness' as with their more cosmopolitan selves.

\section{Conclusion}

Madeleine Dobson (2009) has discussed how children moving with their families can influence the process of migration even when they have no choice in the move itself. Children separated from their families by migration also influence the outcomes in their own ways: for example, 
making choices to resist or comply with decisions that affect them; making the most of the experience or reacting with lingering anger and resentment. Much of the literature on youth who 'return' to their parents' homelands focuses on their more negative responses; on their struggles, resentment and alienation. In the Tongan case it also would be easy to focus on the risks and challenges young people face as they cope with their poor language and cultural skills as well as 'the hard life' they encounter. What this would neglect are the more positive outcomes, including in some cases a profound shift in the young person's sense of self and identity.

There are many factors influencing their experiences, in addition to each young person's own agency in coping with life in Tonga. Clearly, boys living out 'in the bush' at Toloa have a much harder life than the students at Tonga High School, a co-educational day school in Nuku'alofa where classes are in English and students are not expected to spend long hours toiling in the school plantations. Yet in each of the schools there were students finding positive aspects of their time in Tonga, particularly their gradual transformation from being mocked as a 'pālangi to being accepted by others and, importantly, by themselves as truly Tongan.

\section{Acknowledgements}

The project was undertaken through La Trobe University, with funding from the Australian Research Council Discovery Projects scheme, 2012-14. My thanks to the Government of Tonga for permission to conduct this research and to Rebecca Tauali' $i$ and Ebonie Fifita, who did an excellent job of running the school talanoa sessions. I am grateful to the students for their enthusiastic participation and to the schools that allowed us to work with their students; as well as to the adult Tongans who also participated. Mãlo aupito to Meliame Fifita and Hainoame Fulivai for their valuable contributions to the project.

\section{References}

Arowolo, O 2000, 'Return migration and the problem of reintegration', International Migration, vol. 38, no. 5, pp. 59-80. doi.org/10.1111/ 1468-2435.00128 
Barrow, C 2010, Caribbean childhoods: 'outside,' 'adopted' or 'left behind'. good enough parenting and moral families, Ian Randle Publishers, Kingston.

Bohr, Y \& Tse, C 2009, 'Satellite babies in transnational families: a study of parents' decision to separate from their infants', Infant Mental Health Journal, vol. 30, no. 3, pp. 265-286. doi.org/10.1002/imhj.20214

Christou, A \& King, R 2006, 'Migrants encounter migrants in the city: the changing context of "home" for second-generation GreekAmerican return migrants', International Journal of Urban and Regional Research, vol. 30, no. 4, pp. 816-835. doi.org/10.1111/j.1468-2427. 2006.00697.x

Coe, C 2008, 'The structuring of feeling in Ghanaian transnational families', City and Society, vol. 20, no. 2, pp. 222-250. doi.org/ 10.1111/j.1548-744X.2008.00018.x

Connell, J 1990, 'Modernity and its discontents: migration and change in the South Pacific', in J Connell (ed.), Migration and development in the South Pacific, Pacific Research Monograph No. 24, The Australian National University, Canberra, pp. 1-28.

Conway, D \& Potter R, 2007, 'Caribbean transnational return migrants as agents of change', Geography Compass, vol. 1, no. 1, pp. 25-45. doi.org/10.1111/j.1749-8198.2006.00001.x

Conway, D \& Potter, R (eds) 2009, Return migration of the next generations: 21st century transnational mobility, Ashgate, Farnham.

Dobson, M 2009, 'Unpacking children in migration research', Children's Geographies, vol. 7, no. 3, pp. 355-360. doi.org/10.1080/ 14733280903024514

Dreby, J 2007, 'Children and power in Mexican transnational families', Journal of Marriage and Family, vol. 69, pp. 1050-1064. doi.org/ 10.1111/j.1741-3737.2007.00430.x

Esser, J 2011, 'From hyperghettoization to the hut: dilemmas of identity among transmigrant tipoti in the Kingdom of Tonga', $\mathrm{PhD}$ thesis, University of Minnesota.

Gmelch, G 1980, 'Return migration', Annual Review of Anthropology, vol. 9, pp. 135-159. doi.org/10.1146/annurev.an.09.100180.001031 
Guarnizo, L 1997, 'The emergence of a transnational social formation and the mirage of return migration among Dominican transmigrants', Identities, vol. 4, pp. 281-322. doi.org/10.1080/1070289X.1997. 9962591

Hatfield, M 2010, 'Children moving "home"? Everyday experiences of return migration in highly skilled households', Childhood, vol. 17, pp. 243-256. doi.org/10.1177/0907568210365747

James, K 1991, 'Migration and remittances: a Tongan village perspective', Pacific Viewpoint, vol. 32, no. 1, pp. 1-23.

Lee, H 2003, Tongans overseas: between two shores, University of Hawai $\mathrm{i}$ Press, Honolulu.

Lee, H 2009, 'The ambivalence of return: second-generation Tongan returnees', in D Conway \& R Potter (eds), Return of the next generations: 21st century transnational mobility, Ashgate, Farnham, pp. 41-58.

Macpherson, C 1985, 'Public and private views of home: will Western Samoan migrants return?', Pacific Viewpoint, Special Issue: Mobility and Identity in the South Pacific, vol. 26, no. 1, pp. 242-262.

Maron, N \& Connell, J 2008, 'Back to Nukunuku: employment, identity and return migration in Tonga', Asia Pacific Viewpoint, vol. 49, no. 2, pp. 168-184. doi.org/10.1111/j.1467-8373.2008.00368.x

Matthei, L \& Smith, D 1998, 'Belizean “Boyz 'n the 'Hood”? Garifuna labour migration and transnational identity', in $M$ Smith \& L Guarnizo (eds), Transnationalism from below, Transaction Publishers, New Brunswick, pp. 270-290.

Menjivar, C 2002, 'Living in two worlds? Guatemalan-origin children in the United States and emerging transnationalism', Journal of Ethnic and Migration Studies, vol. 28, no. 3, pp. 531-555. doi.org/ $10.1080 / 13691830220146590$

Ministry of Training, Employment, Youth and Sports 2007, The Tonga National Youth Strategy 2007-2012, Kingdom of Tonga, Nuku'alofa.

Moran-Taylor, M 2008, 'When mothers and fathers migrate north: caretakers, children, and child rearing in Guatemala', Latin American Perspectives, vol. 35, pp. 79-95. doi.org/10.1177/0094582X08318980 
Morton, H 2002, 'Creating their own culture: Diasporic Tongans', in P Spickard, J Rondilla \& D Hippolite Wright (eds), Pacific diaspora: Island peoples in the United States and across the Pacific, University of Hawai'i Press, Honolulu, pp.135-149.

Orellana, M, Thorne, B, Chee, A \& Lam, WSE 2001, 'Transnational childhoods: the participation of children in processes of family migration', Social Problems, vol. 48, no. 4, pp. 572-591. doi.org/ $10.1525 /$ sp.2001.48.4.572

Panagakos, A 2004, 'Recycled odyssey: creating transnational families in the Greek diaspora', Global Networks, vol. 4, no. 3, pp. 299-311. doi.org/10.1111/j.1471-0374.2004.00095.x

Parrenas, R 2001, 'Mothering from a distance: emotions, gender and intergenerational relations in Filipino transnational families', Feminist Studies, vol. 27, no. 2, pp. 361-390. doi.org/10.2307/3178765

Pereira, N 2011, 'Return[ed] to paradise: the deportation experience in Samoa and Tonga', MOST-2 Policy Paper 21, UNESCO, Paris.

Potter, R \& Phillips, J 2006a, 'Both black and symbolically white: the "Bajan-Brit" return migrant as post-colonial hybrid', Ethnic and Racial Studies, vol. 29, no. 5, pp. 901-927. doi.org/10.1080/ 01419870600813942

Potter, R \& Phillips, J 2006b, “Mad dogs and transnational migrants?” Bajan-Brit second-generation migrants and accusations of madness', Annals of the Association of American Geographers, vol. 96, no. 3, pp. 586-600. doi.org/10.1111/j.1467-8306.2006.00707.x

Schoone, A 2008, 'Re-scripting life: the experiences of New Zealandborn Tongan "youth at-risk" sent to Tonga', MA thesis, Development Studies, University of Auckland.

Schoone, A 2010, 'Re-scripting life: New Zealand-born Tongan "youthat-risk" narratives of return migration', MAI Review, vol. 1, pp. 1-11.

Suarez-Orozco, C, Todorova, I \& Louie, J 2002, 'Making up for lost time: the experiences of separation and reunification among immigrant families', Family Process, vol. 41, no. 4, pp. 625-643. doi.org/10.1111/ j.1545-5300.2002.00625.x 
Tetteh, E 2008, “My parents are "burghers"': a study of international labour migration and families in Ghana', $\mathrm{PhD}$ thesis, University of Tromso, Norway.

Tsuda, T 2009, Diasporic homecomings: ethnic return migration in comparative perspective, Stanford University Press, Stanford.

Turner, V 1967, The forest of symbols, Cornell University Press, Ithaca, New York.

Vaioleti, T 2006, 'Talanoa research methodology: a developing position on Pacific research', Waikato Journal of Education, vol. 12, pp. 21-34.

Van Gennep, A 1960 [1909], The rites of passage, translated by Monika B Vizedom and Gabrielle L Caffee, University of Chicago Press, Chicago.

Wessendorf, S 2007, “Roots migrants": transnationalism and "return" among second-generation Italians in Switzerland', Journal of Ethnic and Migration Studies, vol. 33, no. 2, pp. 1083-1102. doi.org/10.1080/ 13691830701541614

Whitehouse, B 2009, 'Transnational childrearing and the preservation of transnational identity in Brazzaville, Congo', Global Networks, vol. 9, no. 1, pp. 82-99. doi.org/10.1111/j.1471-0374.2009.00243.x

Zhou, M 1998, "'Parachute kids" in Southern California: the educational experience of Chinese children in transnational families', Educational Policy, vol. 12, pp. 682-703. doi.org/10.1177/0895904898012006005

Zúniga, V \& Hamann, E 2009, 'Sojourners in Mexico with U.S. school experience: a new taxonomy for transnational students', Comparative Education Review, vol. 53, online. doi.org/10.1086/599356 
This text is taken from Mobilities of Return: Pacific Perspectives, edited by John Taylor and Helen Lee, published 2017 by ANU Press, The Australian National University, Canberra, Australia.

dx.doi.org/10.22459/MR.12.2017.04 